\title{
Is it necessary to use prophylactics for preventing PONV?
}

\author{
Jae Hang Shim \\ Depatment of Anesthesiology and Pain Medicine, Hanyang University Hospital, Guri, Korea
}

Postoperative nausea and vomiting (PONV) are common and distressing postsurgical symptoms [1] which continue to be a significant concern for anesthesiologists. PONV occurs in $20 \%$ to $30 \%$ of the general population underwent surgery and in up to $70 \%$ to $80 \%$ of high risk patients $[2,3]$.

PONV is a complex physiologic phenomenon involving multiple neurophysiologic pathways with both central and peripheral receptor mechanisms. A variety of factors have been associated with an increased incidence of postoperative nausea and vomiting. The most frequently described patient-specific risk factors for PONV are female gender, non-smokers, types of surgery such as laparoscopic surgery $[4,5]$ or head and neck surgery, previous history of PONV or motion sickness, and use of intra-operative or postoperative opioids [3]. Postoperative analgesia with opioids is associated with an incidence of PONV of over $30 \%$ [6].

Thyroidectomy is also associated with a relatively high incidence of PONV. The incidence of PONV after thyroidectomy has a reporting rate of $60-76 \%$ according to previous study [7]. PONV after thyroidectomy surgery might be the main source of discomfort, and it may be perceived as the most unpleasant aspect of postoperative recovery [8]. Being able to identify patient-specific risk factors should help clinicians determine appropriate prophylactic treatment for PONV.

Many clinicians have used different types of anti-emetics such as anticholinergic drug, 5-hydroxytryptamine 3 (5-HT3) antagonist or NK-1 antagonist for the treatment of PONV. Ramosetron is a newly developed 5-HT3 receptors antagonist with a more potent and longer receptor antagonizing effect compared with other 5-HT3 receptors antagonists [9].

In this issue of the Korean Journal of Anesthesiology, Lee et al. [10] report on the antiemetic effect of ramosetron with thyroidectomy for PONV. This clinical trial demonstrates the preventative effect of ramosetron for PONV in women undergoing total thyroidectomy with propofol-based total intravenous anesthesia (TIVA). The authors concluded that ramosetron was effective at reducing the incidence and severity of postoperative nausea in women that underwent total thyroidectomy with propofol-based TIVA during first 6 hours postoperatively. Nevertheless there are some debatable points in this paper.

The incidences of postoperative nausea in the control and the ramosetron groups were $29 \%$ and $12 \%$ during first 6 postoperative hours respectively. From a statistical point of view, ramosetron is obviously more effective than control during first 6 postoperative hours $(\mathrm{P}=0.029)$. But there were no differences between ramosetron and control (saline) after 6 hours postoperatively. Also postoperative vomiting was not different all time periods on both groups. The incidence of PONV on the control group was not that high and widely different compared to the ramosetron group in this study as the authors mentioned. While many practitioners believe that 5-HT3 antagonists are relatively safe medications, it is uncertain whether the antiemetic effects of 5-HT3 antagonists are better than inexpensive drugs such as droperidol or metoclopramide clinically. There is also uncertainty about benefit of ramosetron in patients undergoing TIVA.

Cost-effective management is often referred to as an important medical issue. Recently, medical budgets are not sufficient for medical services of all patients in our country. Therefore, we need to be concerned about reduction of medical costs. In Korea, ramosetron (approximately US \$55 for $0.3 \mathrm{mg}$ ) is much more expensive than other commonly used antiemetics,

Corresponding author: Jae Hang Shim, M.D., Depatment of Anesthesiology and Pain Medicine, Hanyang University Hospital, 249-1 Gyomundong, Guri 471-701, Korea. Tel: 82-31-560-2390, Fax: 82-31-563-1731, E-mail: jhshim@hanyang.ac.kr

(c) This is an open-access article distributed under the terms of the Creative Commons Attribution Non-Commercial License (http:// creativecommons.org/licenses/by-nc/3.0/), which permits unrestricted non-commercial use, distribution, and reproduction in any medium, provided the original work is properly cited. 
such as metoclopramide.

Many risk scoring systems for predicting PONV have been mentioned at present [3]. An evaluation of these risk factors allows clinicians to appropriately plan for prophylaxis and treatment of PONV. Eberhart suggests the use of simplified algorithms that could lead to a benefit for a larger proportion of patients [11]. Clearly, such a risk score-adapted preventive strategy for PONV may be viewed as an efficient method for PONV treatment.

The first strategy in reducing the incidence of postoperative nausea and vomiting is to reduce the baseline risk factors for each patient. Patients with a low risk of PONV generally do not require prophylactic medication. Patients at moderate or high risk should receive antiemetic therapy with high cost-effective drugs.

Additionally, inexpensive and comprehensive multimodal managements for preventing PONV should be considered perioperatively. The use of propofol and the avoidance of nitrous oxide add to reductions of the incidence of PONV [12,13]. Other simple methods such as maintaining adequate hydration, minimizing the use of opioid analgesics for preventing postoperative pain in high risk patients, and P-6 acupoint stimulation [14] are also available.

\section{References}

1. Rowbotham DJ, Smith G. Introduction to supplement on postoperative nausea and vomiting. Br J Anaesth 1992; 69(1 Suppl): 1s.

2. Thompson DP, Ashley FL. Face-lift complications: a study of 922 cases performed in a 6-year period. Plast Reconstr Surg 1978; 61: 40-9.

3. Apfel CC, Läärä E, Koivuranta M, Greim CA, Roewer N. A simplifed risk score for predicting postoperative nausea and vomiting : conclusions from cross-validations between two centers. Anesthesiology 1999; 91: 693-700.

4. Lee D, Kim JY, Shin JW, Ku CH, Park YS, Kwak HJ. The effect of oral and IV ramosetron on postoperative nausea and vomiting in patients undergoing gynecological laparoscopy with total intravenous anesthesia. J Anesth 2009; 23: 46-50.

5. Watcha MF, White PF. Postoperative nausea and vomiting. Its etiology, treatment, and prevention. Anesthesiology 1992; 77: 16284.

6. Gepstein R, Arinzon Z, Folman Y, Shuval I, Shabat S. Efficacy and complications of patient controlled analgesia treatment after spinal surgery. Surg Neurol 2007; 67: 360-6.

7. Sonner JM, Hynson JM, Clark O, Katz JA. Nausea and vomiting following thyroid and parathyroid surgery. J Clin Anesth 1997; 9: 398-402.

8. Apfel CC, Kranke P, Eberhart LH. Comparison of surgical site and patient's history with a simplified risk score for the prediction of postoperative nausea and vomiting. Anaesthesia 2004; 59: 1078-82.

9. Kang YK, Park YH, Ryoo BY, Bang YJ, Cho KS, Shin DB, et al. Ramosetron for the prevention of cisplatin-induced acute emesis: a prospective randomized comparison with granisetron. J Int Med Res 2002; 30: 220-9.

10. Lee DC, Kwak HJ, Kim HS, Choi SH, Lee JY. The preventative effect of ramosetron on postoperative nausea and vomiting after total thyroidectomy. Korean J Anesthesiol 2011; 61: 154-8.

11. Eberhart LH, Morin AM. Risk scores for predicting postoperative nausea and vomiting are clinically useful tools and should be used in every patient: Con - 'life is really simple, but we insist on making it complicated.' Eur J Anaesthesiol 2011; 28: 155-9.

12. Shinn HK, Lee MH, Moon SY, Hwang SI, Lee CS, Lim HK, et al. Post-operative nausea and vomiting after gynecologic laparoscopic surgery: comparison between propofol and sevoflurane. Korean J Anesthesiol 2011; 60: 36-40.

13. Apfel CC, Korttila K, Abdalla M, Kerger H, Turan A, Vedder I, et al; IMPACT Investigators. A factorial trial of six interventions for the prevention of postoperative nausea and vomiting. N Engl J Med 2004; 350: 2441-51.

14. Kim YH, Kim KS, Lee HJ, Shim JC, Yoon SW. The efficacy of several neuromuscular monitoring modes at the $\mathrm{P} 6$ acupuncture point in preventing postoperative nausea and vomiting. Anesth Analg 2011; 112: 819-23. 